\title{
Quantification of minerals and tocopherols isomers in chestnuts approach chemometrics
}

\section{Quantificação de minerais e isômeros de tocoferóis em castanhas através da abordagem quimiométrica}

\author{
Nilson Evelazio de Souza ${ }^{1 *}$; Angela Claudia Rodrigues²; Aloisio Henrique Pereira \\ Souza $^{3}$; Makoto Matsushita ${ }^{4}$, Mayka Reghiany Pedrão ${ }^{1}$; Lucia Felicidade Dias ${ }^{1}$
}

\begin{abstract}
The levels of the $\alpha, \delta$, and $(\beta+\gamma)$-tocopherol isomers and the amounts of the minerals $\mathrm{Se}, \mathrm{Zn}, \mathrm{Ca}, \mathrm{Fe}, \mathrm{K}$, $\mathrm{Mn}, \mathrm{Mg}$, and $\mathrm{Cu}$ were analyzed in chestnuts. High contents of $\mathrm{Zn}(>65 \%)$ relative to the recommended dietary intake (RDI) were found in all chestnuts except macadamia nuts ( $25 \%$ of the RDI). All samples had Se contents higher than the RDI: Brazil nuts $>$ macadamia nuts, cashew nuts $>$ pecans $>$ almonds $>$ pistachio nuts $>$ hazelnuts $>$ European nuts. A greater concentration of $\alpha$-tocopherol was found in almonds (30\% of RDI). All samples, except for hazelnuts, almonds, and macadamia nuts, had $(\gamma+\beta)$ tocopherols, with the largest amount found in pistachios. Only pecan nuts and European nuts had $\delta$-tocopherol and only in low amounts. Multivariate analysis allowed for better characterization and distinction of the chestnuts.
\end{abstract}

Key words: Principal component analysis, antioxidants, selenium, zinc

\section{Resumo}

Os níveis dos isômeros $\alpha, \delta$, e $(\beta+\gamma)$-tocoferol e os valores dos minerais $\mathrm{Se}, \mathrm{Zn}, \mathrm{Ca}, \mathrm{Fe}, \mathrm{K}, \mathrm{Mn}, \mathrm{Mg}$ e $\mathrm{Cu}$ foram analisados em castanhas de oleaginosas. Teores elevados de $\mathrm{Zn}(>65 \%)$ em relação à ingestão dietética recomendada (RDI), foram encontrados em todas as castanhas exceto na macadâmia ( $25 \%$ de RDI). Todas as amostras apresentaram elevados teores de Se com relação à RDI, em ordem decrescente: castanha do Brasil $>$ macadâmia, castanha de caju $>$ pecans $>$ amêndoas $>$ pistache $>$ avelãs $>$ nozes europeus. $\alpha$-tocoferol foi encontrado em maior concentração nas amêndoas ( $30 \%$ de RDI). Todas as amostras, exceto para as avelãs, amêndoas e nozes de macadâmia, tinham $(\gamma+\beta)$-tocoferol, com destaque para a alta quantidade encontrada em pistache. $\delta$-tocoferol em pequenas quantidades foram encontradas em nozes pecan e castanha europeia. A análise multivariada permitiu melhor caracterização e distinção das castanhas.

Palavras-chave: Análise de componentes principais, antioxidantes, selênio, zinco

\footnotetext{
${ }^{1}$ Profs. do Mestrado em Tecnologia de Alimentos, Universidade Tecnológica Federal do Paraná, UTFPR, Londrina, PR, Brasil. E-mail: nesouza@uem.br; maikapedrao@utfpr.edu.br; 1fdias@utfpr.edu.br

2 Prof ${ }^{a}$, Universidade Tecnológica Federal do Paraná, UTFPR, Medianeira, PR, Brasil. E-mail: angelac@utfpr.edu.br

${ }^{3}$ Discente Doutorando em Ciências de alimentos da Universidade Estadual de Maringá, UEM, Maringá, PR, Brasil. E-mail: souzaahps@gmail.com

${ }^{4}$ Prof., Universidade Estadual de Maringá, UEM, Maringá, PR, Brasil. E-mail: mmakoto@uem.br

* Author for correspondence
} 


\section{Introduction}

Chestnuts are edible seeds incased in a hard shell that contain low water content and a high content of oil or starch. Seeds in this category include European nuts, almonds, Brazil nuts, hazelnuts, pistachios, and others. Their beneficial effects to health are attributed to their lipid content, their phytochemical components, and antioxidant compounds such as tocopherol isomers (vitamin E) (KORNSTEINER; WAGNER; ELMADFA, 2006).

Chestnuts are also regarded as a food class with a significant amount of minerals, such as Se and Zn (DELGADO-ZAMARREÑO et al., 2001), which act as antioxidants when bound to certain enzymes in the body (DUNDAR; ALTUNDAG, 2004).

Antioxidants protect the body against undesirable free radicals. Excess free radicals are known to play a major role in pathologies such as certain types of cancer, arteriosclerosis, and inflammatory diseases. Antioxidants prevent the attack of free radicals on biomolecules (ARRANZ et al., 2008) such as proteins, nucleic acids, and circulating lipids or lipids in cell membranes (DELGADOZAMARREÑO et al., 2001; MIRALIAKBARI; SHAHIDI, 2008). They can also have a cardioprotective effect by reducing LDL cholesterol oxidation (CHISHOLM et al., 2005; YANG; LIU; HALIM, 2009; ALEXIADOU; KATSILAMBROS, 2011). This particular effect is important because current evidence indicates that oxidative damage contributes to cancer, atherosclerosis, and other chronic diseases (LÓPEZ-URIARTE et al., 2010).Therefore, ingestion of foods containing antioxidants is of major importance for a healthy life (KORNSTEINER; WAGNER; ELMADFA, 2006).

The antioxidant activities of some of these molecules hinge on their capacity to donate a hydrogen atom to free radicals. Because these compounds are able to eliminate free radicals (OLIVEIRA et al., 2008; PEREIRA et al., 2008; ESFAHLAN; JAMEI; ESFAHLAN, 2010), they are believed to have potential in the prevention of cancer, atherosclerosis, diabetes (OLIVEIRA et al., 2008), Alzheimer, Parkinson, and other degenerative diseases (VILLARREAL-LOZOYA; LOMBARDINI; CISNEROS-ZEVALLOS, 2007).

Tocopherol belongs to the group of liposoluble vitamins and comprises eight basic natural components: four tocopherols and four tocotrienols, which are identified by the prefixes $\alpha, \beta, \gamma$, and $\delta$. The isomers are solely produced by plants and their activities are different from those of vitamin E. Among the various forms of vitamin E, $\alpha$-tocopherol is the most biologically active (YADA; LAPSLEY; HUANG, 2011).

As powerful antioxidants, tocopherols can reduce the risk of cardiac disease through the inhibition of LDL cholesterol oxidation (YANG; LIU; HALIM, 2009) and can also help reduce the risk of some chronic diseases such as type-2 diabetes and cancer (KÖKSAL et al., 2006). Protection against tumors at different sites may occur through the inhibition of cell proliferation (YANG; LIU; HALIM, 2009). The consumption of tocopherols also counteracts some of the negative effects associated with aging and prevents cognitive decline and Alzheimer's disease (KÖKSAL et al., 2006).

Se is an important component of antioxidant enzymes that protect cells against the effects of free radicals involved in the development of some chronic diseases (DUNDAR; ALTUNDAG, 2004; YANG; LIU; HALIM, 2009). They participate in the prevention of diseases such as cancer (especially lung, breast, and prostate cancer) and cardiovascular diseases (YANG; LIU; HALIM, 2009; PAREKH et al., 2008; FREITAS-SILVA; VENÂNCIO, 2011).

The anticancer activity of Se is observed when it combines with tocopherols and other antioxidants. The chemoprotective mechanisms of Se that assist DNA repair can be attributed to its capacity to act as an antioxidant. Se can also contribute to improve mood and mental performance in patients with early Alzheimer's disease (RUKMINI, 2000). 
Several studies have demonstrated that $\mathrm{Zn}$ supplements can reduce oxidative damage. However, it is known that $\mathrm{Zn}$ does not act as an antioxidant directly. Several studies have also reported the anti-atherosclerotic action of $\mathrm{Zn}$ and its benefits in cardiovascular diseases (JENNER et al., 2007).

Multivariate analysis enables extraction of additional information when compared to univariate analysis. This latter chemometric tool allows for pattern recognition, the gathering of information, the reduction of data dimensionality, and the organization of data in a simpler, easier to understand structure. Principal component analysis (PCA) is based on performing linear comparisons of the original variables. The principal components (PC) are mutually orthogonal, and the explained variance decreases with an increase in the number of PCs (CORREIA; FERREIRA, 2007).

Quality composition data are also essential for nutrition researchers, health professionals, and for food labeling (YADA; LAPSLEY; HUANG, 2011). Considering the nutritional importance and differences in composition of oleaginous seeds due to environmental conditions, culture practices and species traits, characterization of their nutrients is of great importance. This study investigated the isomers $\alpha, \delta$ and $(\beta+\gamma)$-tocopherol (vitamin E) and assessed the activities of total vitamin $E$ $(\alpha-\mathrm{TE})$ as well as the amounts of $\mathrm{Se}$ and $\mathrm{Zn}$ and other minerals such as $\mathrm{Ca}, \mathrm{Fe}, \mathrm{K}, \mathrm{Mn}, \mathrm{Mg}$, and $\mathrm{Cu}$ using chemometric analysis in chestnuts usually consumed by the Brazilian population. The principal component analysis (PCA) was applied to extract more information from the data.

\section{Experimental}

\section{Sampling}

Samples of macadamia, pecan and Brazil nuts, raw cashew nuts $(\mathrm{R})$, and salted roasted cashew nuts (SRO) were purchased from various stores in Brazil. European nuts, raw almonds (R), and salted roasted almonds (SRO) were imported from Chile. Raw pistachios, salted roasted pistachios (SRO), and hazelnuts were imported from the USA and Turkey, respectively. Three brands of each nut and three lots of each brand were analyzed in triplicate.

The samples were ground in a food processor until they were homogeneous; they were then vacuum packed, wrapped in aluminum foil for light protection, and frozen stored until analysis.

\section{Mineral determination}

The samples were submitted to wet-route digestion: $10 \mathrm{~mL}$ of nitric acid was added to approximately $1.0000 \pm 0.0001 \mathrm{~g}$ of each sample in a $100 \mathrm{~mL}$ glass tube. The mixture was rested overnight before the samples were placed in a digestor block analysis at $100{ }^{\circ} \mathrm{C}$ for $4 \mathrm{~h}$. After digestion, the sample volume was brought up to $25 \mathrm{~mL}$ with deionized water in a volumetric flask (BOHRER et al., 2007).

All minerals, except Se, were analyzed in a flame atomic absorption spectrometry (FAAS) (AA240FS - VARIAN). Se was analyzed by atomic absorption using the graphite oven atomization technique.

The amount of minerals in the samples was assessed by the analytical curve method, with solutions of each mineral prepared at different concentrations (INSTITUTO ADOLFO LUTZ, 2005).

The RDI values were used to calculate the percent contributions of the analyzed minerals in foods for adults, except for K, which does not yet have an RDI. The mineral quantification results were used to calculate the percent contribution to RDI in adults in $100 \mathrm{~g}$ samples.

\section{Determination of tocopherol isomers and equivalent vitamin $E$}

The saponified and vitamin E isomers samples were extracted as described by Delgado-Zamarreño 
et al. (2004) with the extraction time modified to $4 \mathrm{~h}$ under agitation. Fifty milliliters of ethanol, $5.0 \mathrm{~mL}$ of a $10 \%(\mathrm{~m} / \mathrm{v})$ aqueous solution of ascorbic acid, $10 \mathrm{~mL}$ of $80 \%(\mathrm{~m} / \mathrm{v})$ aqueous solution of potassium hydroxide, and $25 \mathrm{~mL}$ of water were added to 2.000 $\mathrm{g}$ of ground sample and were protected from light. The non-saponifiable material was extracted with hexane and water. The organic phase was evaporated in a rotary evaporator under vacuum at $50{ }^{\circ} \mathrm{C}$; the residue was dissolved in methanol.

Chromatographic Separation of tocopherol isomers and equivalent vitamin was carried out using a Varian ProStar System with Star Chromatography Workstation and LC control software (Varian Analytical Instruments) comprising ProStar 240 solvent delivery modules, a Model ProStar 410 Auto Sampler with a sample loop of $40 \mathrm{~mL}$, a Model ProStar 330 photodiode array detector with the Polyview $2000^{\mathrm{TM}}$ program, and a microsorb C18 $250 \times 4.6 \mathrm{~mm}$ column with $5 \mu \mathrm{m}$ particles equipped with a microsorb C18 $10 \times 4 \mathrm{~mm}$ guard column. The carrier phase used was methanol/dichloromethane at a ratio of $85: 15(\mathrm{v} / \mathrm{v})$; the flow rate was $0.8 \mathrm{~mL}$ min $^{-1}$ (KORNSTEINER; WAGNER; ELMADFA, 2006). Tocopherols were quantified by the external standard method, following Instituto Adolfo Lutz (2005). The sum of the $\beta$-tocopherol and $\gamma$-tocopherol isomers was determined. It was not possible to separate them by this methodology (KORNSTEINER; WAGNER; ELMADFA, 2006).

The activity of vitamin $E$ in the samples was determined according to Kornsteiner, Wagner and Elmadfa (2006) by multiplying the value found for each isomer, in $\mathrm{mg}$, and the equivalent factor for $\alpha$-tocopherol, $\alpha$-TE. For $\alpha$-tocopherol, $\alpha$-TE $=\operatorname{mg~x}$ 1.0; for $(\beta+\gamma)$-tocopherol, $\alpha-\mathrm{TE}=\operatorname{mg} \times \mathrm{x} 0.25$; and for $\delta$-tocopherol, $\alpha$-TE $=\operatorname{mg} \times 0.01$.

\section{Statistical analyses}

Mineral quantification and tocopherol isomer analysis were carried out in triplicate. The results were submitted to analyses of variance (ANOVA) and the means were compared using the Tukey's post hoc test. In multivariate analysis, the individual values of each replicate in the three batches analyzed $(\mathrm{n}=99)$ were divided into arrays of data. The samples were arranged in rows (99) and mineral concentrations $(\mathrm{n}=8)$ and isomers of tocopherols $(\mathrm{n}=3)$ columns in respectively the data arrays: 99 $\mathrm{x} 8$ and $99 \times 3$. The data was pre-processed through auto-scaling. In this case, the data are centered on the middle and divide each individual value by the standard deviation. This is done so that all variables have the same value i.e., the same weight. The process was subsequently applied to the Principal Components Analysis (PCA) with the use of the algorithm NIPALS. It was decomposed into a twodimensional graph of scores (samples) and loadings (variables). The statistical software SAS, version 8.1 (SAS, 2000), was used with a 5\% $(\mathrm{p}<0.05)$ significance level for rejection of the null hypothesis and to select principal components.

\section{Results and Discussion}

\section{Minerals}

Table 1 gives the mineral composition of the samples as the mean for different brands of the same nuts. No significant difference was found for any of the minerals investigated in the same type of nut, whether raw or salted and roasted.

Brazil (2005) establishes the recommended daily intake of proteins, vitamins, and minerals that meets the nutritional needs of most individuals in a healthy population.

All RDI values were based on the data of the Institute of Medicine (1999-2001; 2000) of the Food and Agriculture Organization for the United Nations and the World Health Organization (2001). The RDI values are given per age: infants, children, adults, and pregnant and lactating women.

The $\mathrm{Zn}$ values were greater than the RDI in all samples (over 65\%) except for macadamia nuts, which had $1.8 \mathrm{mg} 100 \mathrm{~g}^{-1}$ of sample, equivalent 
to $25 \% \mathrm{RDI}$. The amounts of $\mathrm{Zn}$ decreased in this order: pistachios $>$ Brazil nuts $>$ pecans $>$ cashew nuts $>$ almonds $>$ European nuts $>$ hazelnuts. Zinc had considerable influence on PC1 (Table 2) and was responsible for characterizing the samples of raw pistachios, roasted salted pistachios, roasted salted almonds, raw almonds, salted roasted almonds, and Brazil nuts (Figure 1) due to the high levels of zinc found in these nuts (Table 1).

Figure 1. Principal component analysis of mineral composition in nuts. PC: Principal component. 1. Raw pistachios, 2. Salted roasted pistachios, 3. Hazelnuts, 4. European nuts, 5. Raw almonds, 6. Salted roasted almonds, 7. Raw cashew nuts, 8. Salted raw cashew nuts, 9. Brazil nuts, 10. Pecans, 11. Macadamia nuts.

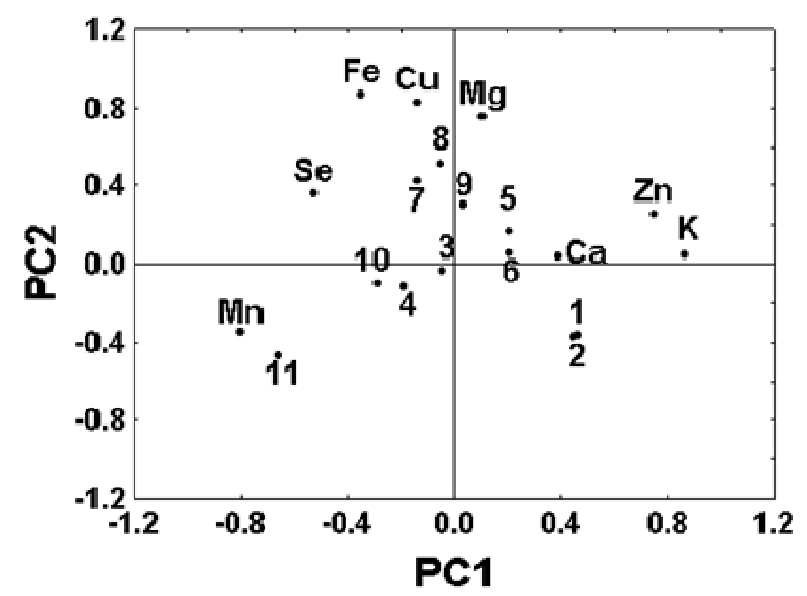

Source: Elaboration of the authors.

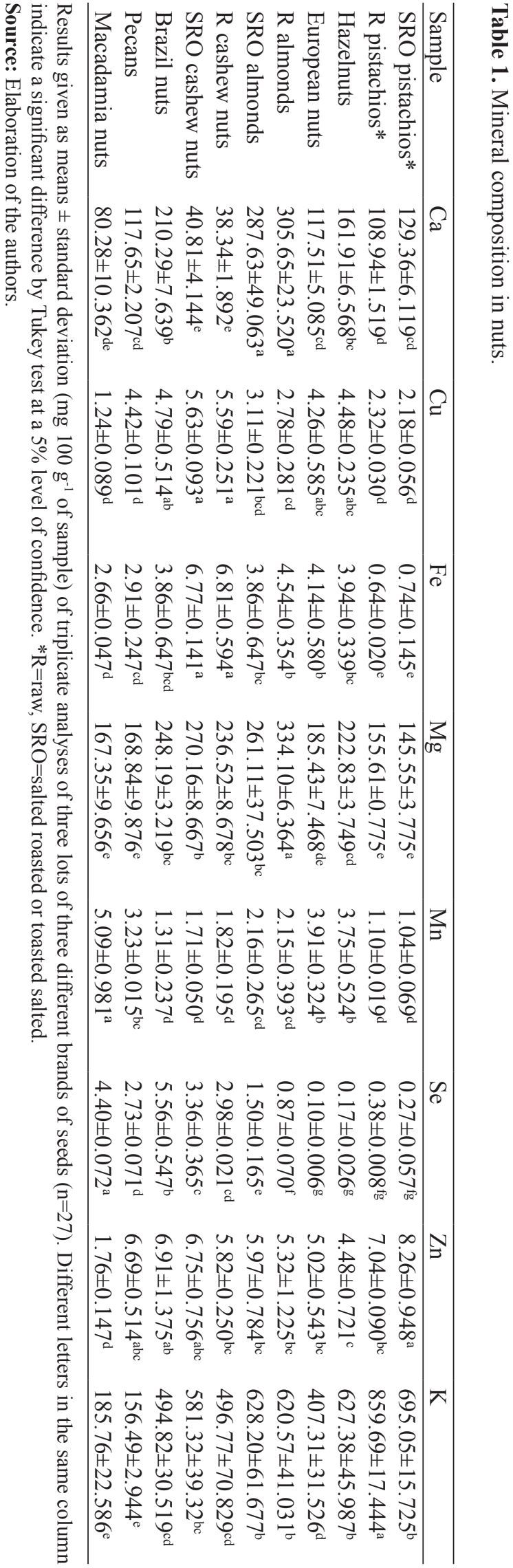


Table 2. Eigen analysis of the correlation matrix loadings of the significant principal component (PC) for mineral quantification and isomers of tocopherols.

\begin{tabular}{|c|c|c|c|c|c|c|c|c|c|c|}
\hline & \multicolumn{10}{|c|}{ Minerals } \\
\hline & Eigenvalues & $\begin{array}{c}\% \text { Total } \\
\text { variance }\end{array}$ & $\mathrm{Ca}$ & $\mathrm{Cu}$ & $\mathrm{Fe}$ & $\mathrm{Mg}$ & $\mathrm{Mn}$ & $\mathrm{Se}$ & $\mathrm{Zn}$ & K \\
\hline PC1 & 3.6187 & 19.0461 & 0.3889 & -0.1378 & -0.3447 & 0.1074 & -0.8010 & -0.5251 & 0.7486 & 0.8699 \\
\hline PC2 & 3.4032 & 17.9118 & 0.0367 & 0.8259 & 0.8682 & 0.7517 & -0.3464 & 0.3628 & 0.2584 & 0.0448 \\
\hline $\mathrm{PC} 3$ & 2.5403 & 13.3701 & 0.8226 & -0.3407 & 0.0773 & 0.6036 & 0.28975 & -0.1696 & -0.422 & 0.0533 \\
\hline \multicolumn{11}{|c|}{ Isomers of tocopherols } \\
\hline & Eigenvalues & $\begin{array}{l}\% \text { Total } \\
\text { variance }\end{array}$ & $\delta$-Tocoferol & $\begin{array}{c}(\gamma+\beta)- \\
\text { Tocoferol }\end{array}$ & $\alpha$-Tocoferol & & & & & \\
\hline $\mathrm{PC} 1$ & 2.7340 & 19.5286 & 0.7240 & 0.7902 & -0.7092 & & & & & \\
\hline PC2 & 1.8108 & 12.9342 & -0.6907 & 0.3085 & -0.3845 & & & & & \\
\hline
\end{tabular}

Source: Elaboration of the authors.

As expected, the highest amount of Se was found in Brazil nuts. Its value was statistically different from those of other seeds. However, it must be observed that all samples had values above the RDI of Se. Macadamia nuts had the second highest amount of Se with $4.4 \mathrm{mg} 100 \mathrm{~g}^{-1}$ of sample, which was different from the other nuts $(\mathrm{p}<0.05)$. That is, the seed ranking for Se content was as follows: Brazil nuts $>$ macadamia nuts $>$ cashew nuts $>$ pecans $>$ almonds $>$ pistachios $>$ hazelnuts $>$ European nuts. The raw cashew nuts, roasted cashew nuts salted, Brazil nuts, pecan nuts and macadamia nuts formed the group characterized by higher selenium content (Table 1). This is confirmed by the high contribution of this mineral in PC2 (Figure 1) and distribution of vector nuts (Table 2).

$\mathrm{Ca}$ was found in greater amounts in almonds. An amount of $100 \mathrm{~g}$ of almonds provides approximately $30 \%$ of the RDI of $\mathrm{Ca}$ and serve as alternative source of Ca. Hazelnuts and Brazil nuts had similar $\mathrm{Ca}$ content and provide $16 \%$ and $20 \%$ of the $\mathrm{Ca}$ RDI, respectively. Pecans, macadamia nuts, and European nuts were statistically equal with contents

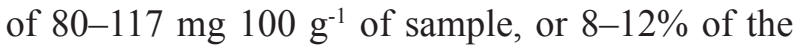
RDI. Cashew nuts had the lowest Ca content: $40 \mathrm{mg}$ $100 \mathrm{~g}^{-1}$ of sample, corresponding to $4 \%$ of the RDI. When analyzing the PC3 (Figure 2), it is possible to distinguish the raw almonds and the salted, roasted almonds due to the amount of calcium, which was primarily responsible for the selection of these samples (Table 2).

Figure 2. Principal component analysis of mineral composition in nuts. PC: Principal component. 1. Raw pistachios, 2. Salted roasted pistachios, 3. Hazelnuts, 4. European nuts, 5. Raw almonds, 6. Salted roasted almonds, 7. Raw cashew nuts, 8. Salted raw cashew nuts, 9. Brazil nuts, 10. Pecans, 11. Macadamia nuts.

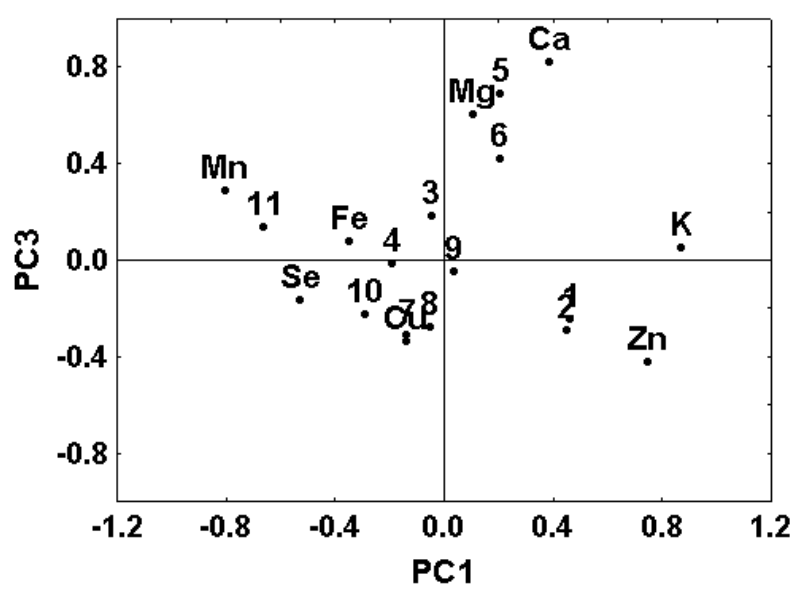

Source: Elaboration of the authors.

The largest amount of $\mathrm{Mg}$ was found in almonds, cashew nuts, and Brazil nuts, corresponding to $90 \%$ of the RDI. This is well illustrated in PC2 (Figure 1). The distinction of these samples is due to the highly significant $\mathrm{Mg}$ contribution in this component (Table 2). Hazelnuts and European nuts presented 
amounts to 71 and $86 \%$ of the RDI. The highest concentration of $\mathrm{Mg}$ was found in macadamia nuts and pecans.

Potassium was present in large quantities in all nuts with the exception of macadamia nuts and pecans. Pistachios, hazelnuts, and almonds had the greatest amount of potassium, from 620 to 860 $\mathrm{mg} 100 \mathrm{~g}^{-1}$ of sample. The amounts in $\mathrm{R}$ pistachio, $\mathrm{R}$ almond, and SR hazelnuts were equal, and SR pistachio was different from all the other samples. Almonds and cashew nuts contained 495 and $581 \mathrm{mg}$ of K per $100 \mathrm{~g}$ of sample, respectively. Multivariate analysis was applied as a means to group the salted roasted pistachio, pistachio raw, raw almonds, and roasted almonds nuts salted on PC1 (Figure 1).This analysis verified greater influence of mineral in PC1 (Table 2) by distinguishing the samples with the highest content. Macadamia nuts and pecans had the lowest amounts

$\mathrm{Cu}$ was found in quantities significantly larger than the RDI (per $100 \mathrm{~g}$ of sample), with cashew nuts having the greatest amounts, that means $620 \%$ of the RDI. The higher copper content (Table 1) in raw cashew and salted and roasted Brazil nuts allowed these scores to be separated by PC2 through the brunt of loading.

Macadamia nuts contained more Mn than the other ones, equivalent to $220 \%$ of the RDI. A statistically equivalent amount of $\mathrm{Mn}$ was found to European nuts, macadamia nuts, hazelnuts and at 3.2 to $3.9 \mathrm{mg} 100 \mathrm{~g}-1$ of sample, all higher than the RDI. The proximate manganese content in European nuts, macadamia nuts, pecan nuts, and hazelnuts differed them from the other nuts. This result can be verified by the negative contribution (Table 2) of this mineral in the left quadrant of the lower PC1 and PC2 (Figure 1). Almonds presented more than $90 \%$ of the RDI of Mn and were statistically equal to each other $(\mathrm{p}<0.05)$ and to cashew nuts, Brazil nuts, and pistachios, which had amounts equal to $75 \%, 57 \%$, and $45 \%$ of the RDI. Mn is the preferred co-factor of enzymes required for the formation of cartilage and healthy bones. It is also a necessity or the development of conjunctive tissue and for the normal reproduction and the metabolism of carbohydrates.

Cashew nuts showed iron content higher the other nuts. The distinction of these scores (samples) appears in the left quadrant of PC1 and PC2 in the top (Figure 1) and includes a high contribution of loading (Fe) corresponding to $50 \%$ of the RDI. The iron content of almonds, European nuts, hazelnuts, and Brazil nuts was similar, ranging from 3.9 to 4.5 mg $100 \mathrm{~g}^{-1}$ of sample, or $25-30 \%$ of the RDI. The iron contents in pecans, macadamia nuts and Brasil nuts, were equal corresponding $20 \%$ of the RDI. Pistachios, by contrast, had lower iron content, which is equal to $5 \%$ of the RDI.

\section{Vitamin E}

The variation in tocopherol contents among the oleaginous seeds is given in Table 3. A greater concentration of $\alpha$-tocopherol was found in $\mathrm{R}$ almonds, followed by SRO hazelnuts, Brazil nuts, pistachios, pecans, cashew nuts, European nuts, and macadamia nuts. R almonds were equal to hazelnuts, Brazil nuts, and SRO pistachios; hazelnuts were equal to Brazil nuts, R and SRO pistachio, pecans, cashew nuts, and European nuts. Brazil nuts and SRO pistachios were different only from SRO almonds. R pistachios, pecan nuts, SRO cashew nuts, and European nuts were statistically equal to each other and different from hazelnuts and R and SRO almonds. Principal components analysis allowed for the selection of PC1 and PC2, which explained the $32.46 \%$ of data variance of isomers tocopherols (Table 2). The $\alpha$-tocopherol levels obtained for the hazelnuts, almonds, cashew nuts, Brazil nuts, and macadamia nuts were responsible for separating these fruits from others, by PC1 (Figure 2) due to the high influence of this loading. This group can be further subdivided into two additional groups by PC2 (Figure 3). These groups include the separation of scores (samples) of hazelnuts, raw almonds, and salted roasted almond with a higher content of $\alpha$-tocopherol isomer. 
Table 3. Mean values of tocopherols in nuts.

\begin{tabular}{llll}
\hline Sample & $\delta$-Tocopherol & $(\gamma+\beta)$-Tocopherol & $\alpha$-Tocopherol \\
\hline SRO pistachios* & nd & $3.46 \pm 0.245^{\mathrm{a}}$ & $1.70 \pm 0.425^{\text {bcd }}$ \\
R pistachios* & nd & $3.38 \pm 0.028^{\mathrm{a}}$ & $1.38 \pm 0.353^{\text {cd }}$ \\
Hazelnuts & nd & nd & $3.01 \pm 0.878^{\text {bc }}$ \\
European nuts & $0.54 \pm 0.028^{\mathrm{a}}$ & $1.96 \pm 0.413^{\text {bc }}$ & $0.96 \pm 0.048^{\text {cd }}$ \\
R almonds & nd & nd & $3.60 \pm 1.407^{\mathrm{b}}$ \\
SRO almonds & nd & nd & $6.35 \pm 1.511^{\mathrm{a}}$ \\
R cashew nuts & nd & $0.76 \pm 0.185^{\mathrm{d}}$ & $0.87 \pm 0.049^{\mathrm{d}}$ \\
SRO cashew nuts & nd & $1.13 \pm 0.094^{\text {cd }}$ & $1.05 \pm 0.170^{\text {cd }}$ \\
Brazil nuts & nd & $1.80 \pm 0.545^{\text {bc }}$ & $2.42 \pm 0.087^{\text {bd }}$ \\
Pecans & $0.61 \pm 0.053^{\mathrm{b}}$ & $2.63 \pm 0.786^{\mathrm{ab}}$ & $1.26 \pm 0.393^{\text {cd }}$ \\
Macadamia nuts & nd & nd & $0.93 \pm 0.064^{\mathrm{d}}$ \\
\hline
\end{tabular}

Results given as means \pm standard deviation ( $\mathrm{mg} 100 \mathrm{~g}^{-1}$ of sample) of triplicate analyses of three lots of three different brands of seeds $(\mathrm{n}=27)$. Different letters in the same column indicate a significant difference by Tukey's test at $5 \%$ level of confidence. $* \mathrm{R}=\mathrm{raw}, \mathrm{SRO}=$ salted roasted or toasted salted, $\mathrm{nd}=$ not detected.

Source: Elaboration of the authors.

With the exception of hazelnuts, almonds, and macadamia nuts, all samples presented $(\gamma+\beta)$ tocopherols in this content order: pistachios $>$ pecans $>$ European nuts $>$ Brazil nuts $>$ cashew nuts. The sum of the tocopherols in pistachios was significantly equal to each other and to that in pecans, Brazil nuts, European nuts, and R and SRO cashew nuts. There was a major contribution to the sum of the isomers $(\gamma+\beta)$-tocopherols (Table 2$)$ for the samples raw and salted roasted pistachios in the top, right quadrant of PC1 and PC2 (Figure 3).

Only pecans and European nuts presented $\delta$-tocopherol, with statistically different values inclusive of the lowest amount found, relative to the other isomers analyzed. The $\delta$-tocopherol isomer was responsible for the differentiation of European fruits and pecan nuts. This effect can be verified with the PC1 versus PC2 (Figure 3), and this isomer was only found in these nuts (Table 3 ).

The total $\alpha$-TE of the samples that contained other isomers of vitamin $\mathrm{E}$, in addition to $\alpha$-tocopherol, was $2.87 \mathrm{mg} 100 \mathrm{~g}^{-1}$ of sample for cashew nuts, $2.5 \mathrm{mg} 100 \mathrm{~g}^{-1}$ of sample in pistachios, $1.92 \mathrm{mg} 100 \mathrm{~g} \mathrm{~g}^{-1}$ of sample for pecans, $1.46 \mathrm{mg} 100$ $\mathrm{g}^{-1}$ of sample in European nuts and $1.3 \mathrm{mg} 100 \mathrm{~g}^{-1}$ of sample for cashew nuts. Therefore, the seeds, in decreasing order of Vitamin E activity, were as follows: almonds $>$ hazel nuts $>$ Brazil nuts $>$ pistachios $>$ pecans $>$ European nuts $>$ cashew nuts $>$ macadamia nuts. It is worth pointing out that no significant variation was observed between $\mathrm{R}$ and SR samples of the same seeds.

Figure 3. Principal component analysis of isomers of tocopherols composition in oleaginous seeds. PC: Principal component. 1. Raw pistachio, 2. Salted roasted pistachio, 3. Halzenuts, 4. European nuts, 5. Raw almonds, 6. Salted roasted almonds, 7. Raw cashew nuts, 8. Salted raw cashew nuts, 9. Brazil nuts, 10. Pecan nuts, 11. Macadamia nuts.

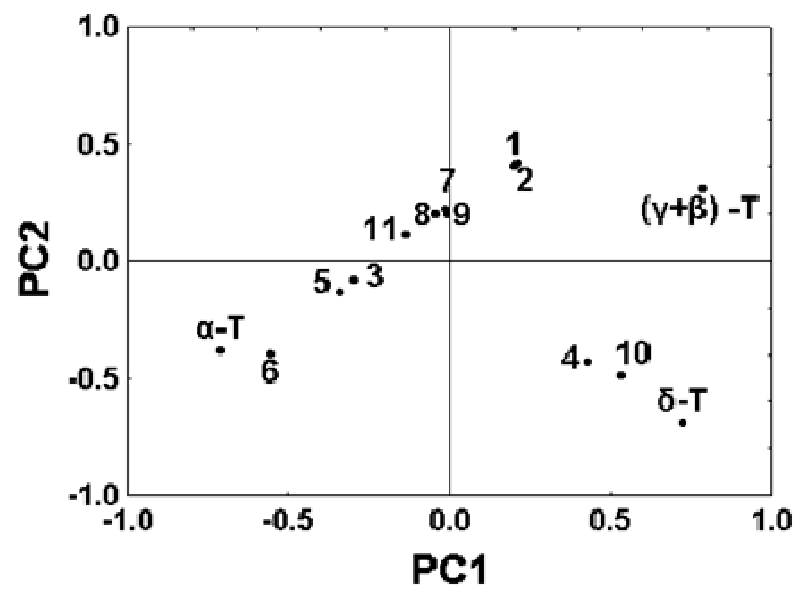

Source: Elaboration of the authors. 
According to the Institute of Medicine (2000), the RDI of $\alpha$-TE for adults is $15 \mathrm{mg}$. Therefore, 100 $\mathrm{g}$ of almonds provide a mean amount of $30 \%$ of the RDI; as such, this particular almond amount the best source of this nutrient among the oleaginous seeds investigated. Comparatively, $100 \mathrm{~g}$ of hazelnuts and Brazil nuts contained $20 \%$ of the RDI, and pistachios contained 17\%. Pecans and European nuts contained $20 \%$ and $15 \%$ of the RDI of $\alpha$-TE in $100 \mathrm{~g}$ of sample. Cashew nuts and macadamia nuts had $6 \%$ and $9 \%$ of the RDI per $100 \mathrm{~g}$ of sample.

\section{Conclusion}

A greater concentration of $\alpha$-tocopherol was found in almonds but all seeds, except for hazelnuts, almonds, and macadamia nuts, had $(\gamma+\beta)$-tocopherols. Only pecans and European nuts had $\delta$-tocopherol, which was in low concentrations. Therefore, the seeds in decreasing order of Vitamin E activity were as follows: almonds $>$ hazel nuts $>$ Brazil nuts $>$ pistachios $>$ pecans $>$ European nuts $>$ cashew nuts $>$ macadamia nuts.

The nuts' ranking in terms of amount of $\mathrm{Zn}$ was pistachios $>$ Brazil nuts $>$ pecans $>$ cashew nuts $>$ almonds $>$ European nuts $>$ hazelnuts. Their ranking in terms of Se content was Brazil nuts $>$ macadamia nuts $>$ cashew nuts $>$ pecan nuts $>$ almonds $>$ pistachio $>$ hazelnuts $>$ European nuts.

Multivariate analysis allowed for a better clustering and distinction of the nuts through their respective mineral compositions and tocopherol isomer content.

\section{References}

ALEXIADOU, K.; KATSILAMBROS, N. Nuts: Anti-atherogenic food? European Journal of Internal Medicine, Amsterdam, v. 22, n. 1, p. 141-146, 2011.

ARRANZ, S.; CERT, R.; PÉREZ-JIMÉNEZ, CERT, A.; SAURA-CALIXTO, F. Comparison between free radical scavenging capacity and oxidative stability of nut oils. Food Chemistry, London, v. 110, n. 4 p. 985-990, 2008.
BOHRER, D.; BECKER, E.; NASCIMENTO, P. C.; DESSUY, M.; CARVALHO, L. M. Comparison of graphite furnace and hydride generation atomic absorption spectrometry for the determination of selenium status in chicken meat. Food Chemistry, London, v. 104, n. 2 p. 868-875, 2007.

BRASIL. Ministério da Saúde. Agência Nacional de Vigilância Sanitária (ANVISA). Resolução RDC $\mathrm{n}^{\circ}$ 269, 22 set. 2005. Disponível em: <http://www.crd. defesacivil.rj.gov.br/documentos/IDR.pdf $>$. Acesso em: 16 jan. 2012.

CHISHOLM, A.; MCAULEY, K.; MAN, J.; WILLIAMS, S.; SKEAF, M. Cholesterol lowering effects of nuts compared with a Canola oil enriched cereal of similar fat composition. Nutrition Metabolism \& Cardiovascular Diseases, Oxford, v. 15, n. 4, p. 284-292, 2005.

CORREIA, P. R. M.; FERREIRA M. C. Non-supervised pattern recognition methods: exploring chemometrical procedures for evaluating analytical data. Química Nova, São Paulo, v. 30, n. 2, p. 481-487, 2007.

DELGADO-ZAMARREÑO, M. M.; GONZALEZMAZA, I.; SANCHEZ-PEREZ, A.; CARABIASMARTINEZ, R. Analysis of vitamin E isomers in seeds and nuts with and without coupled hydrolysis by liquid chromatography and coulometric detection. Journal of Chromatography A, Amsterdan, v. 1056, n. 1-2, p. 77-86, 2004.

Pressurized liquid extraction prior to liquid chromatography with electrochemical detection for the analysis of vitamin E isomers in seeds and nuts. Journal Chromatography A, Amsterdan, v. 1056, n. 1-2, p. 249252, 2001.

DUNDAR, M. S.; ALTUNDAG, H. Selenium content of turkish hazelnut varieties: kara findik, tombul and delisava. Journal of Food Composition and Analysis, San Diego, v. 17, n. 6, p. 707-712, 2004.

ESFAHLAN, A. J.; JAMEI, R.; ESFAHLAN, R. J. The importance of almond (Prunus amygdalus L.) and its byproducts. Food Chemistry, London, v. 120, n. 4, p. 349360, 2010.

FOOD AND AGRICULTURE ORGANIZATION / ORGANIZAÇÃO MUNDIAL DA SAÚDE-FAO/OMS. Human vitamin and mineral requirements. In: Report. $7^{\text {th }}$ ed. Bangkok: Joint Fao/Oms Expert Consultation, 2001. $286 \mathrm{p}$.

FREITAS-SILVA, O.; VENÂNCIO, A. Brazil nuts: benefits and risks associated with contamination by fungi and mycotoxins. Food Research International, Barking, v. 44, n. 5, p. 1434-1440, 2011. 
INSTITUTE OF MEDICINE. Dietary reference intakes for vitamin $\mathrm{C}$, vitamin $\mathrm{E}$, selenium and carotenoids. Washington, DC: National Academy Press, 2000.

Food and nutrition board. Dietary reference intakes. Washington DC: National Academic Press, 1999-2001.

INSTITUTO ADOLFO LUTZ - IAL. Normas analíticas do Instituto Adolfo Lutz. IV - Métodos químicos e físicos para análise de alimentos. $5^{\text {th }}$ ed. São Paulo: IAL, 2005.

JENNER, A.; REN, M.; RAJENDRAN, R.; NING, P.; HUAT, B. T. K.; WATT, F.; HALLIWEL, B. Zinc supplementation inhibits lipid peroxidation and the development of atherosclerosis in rabbits fed a high cholesterol diet. Free Radical Biology \& Medicine, New York, v. 42, n. 4, p. 559-566, 2007.

KÖKSAL, A. I.; ARTIK, N.; SIMSEK, A.; GÜNES, N. Nutrient composition of hazelnut (Corylus avellana L.) varieties cultivated in Turkey. Food Chemistry, London, v. 99 , n. 3, p. 509-515, 2006.

KORNSTEINER, M.; WAGNER, K. H.; ELMADFA, I. Tocopherols and total phenolics in 10 different nut types. Food Chemistry, London, v. 98, n. 2, p. 381-387, 2006.

LÓPEZ-URIARTE， P.; NOGUES， R.; SAEZ， G.; BULLO, M.; ROMEU, M.; MASANA, L.; TORMOS, C.; CASAS-AGUNSTENCH, P.; SALAS-SALVADO, $\mathrm{J}$. Effect of nut consumption on oxidative stress and the endothelial function in metabolic syndrome. Clinical Nutrition, Midlothian, v. 29, n. 3, p. 373-380, 2010.

MIRALIAKBARI, H.; SHAHIDI, F. Antioxidant activity of minor components of tree nut oils. Food Chemistry, London, v. 111, n. 2, p. 421-427, 2008.

OLIVEIRA, I.; SOUSA, A.; MORAIS, J. S.; FERREIRA, I. C. F. R.; BENTO, A.; ESTEVINHO, L.; PEREIRA, J. A. A. Chemical composition, and antioxidant and antimicrobial activities of three hazelnut (Corylus avellana L.) cultivars. Food and Chemical Toxicology, Oxford, v. 46, n. 5, p. 1801-1807, 2008.
PAREKH, P. P.; KHAN, A. R.; TORRES, M. A.; KITTO, M. E. Concentrations of selenium, barium, and radium in Brazil nuts. Journal of Food Composition and Analysis, San Diego, v. 21, n. 4, p. 332-335, 2008.

PEREIRA, J. A.; OLIVEIRA, I.; SOUZA, A.; FERREIRA, I. C. F. R.; BENTO, A.; ESTEVINHO, L. Bioactive properties and chemical composition of six walnut (Juglans regia L.) cultivars. Food and Chemical Toxicology, Oxford, v. 46, n. 6, p. 2103-2111, 2008.

RUKMINI, C. Bioactives in rice bran and rice bran oil. In: BIDLACK, W. R.; OMAYE, S. T.; MESKIN, M. S.; TOPHAM, D. K. W.; LANCASTER, P. A. (Ed.). Phytochemicals as bioactive agents. Cleveland: Technomic, 2000. p. 213-239.

STATISTICAL ANALYSIS SYSTEM INSTITUTE SAS. SAS Institute. System for informatic. Version 8.1. Cary, 2000.

VILLARREAL-LOZOYA, J. E.; LOMBARDINI, L.; CISNEROS-ZEVALLOS, L. Phytochemical constituents and antioxidant capacity of different pecan [Carya illinoinensis (Wangenh.) K. Koch] cultivars. Food Chemistry, London, v. 102, n. 3, p. 1241-1249, 2007.

YADA, S.; LAPSLEY, K.; HUANG, G. A review of composition studies of cultivated almonds: Macronutrients and micronutrients. Journal of Food Composition and Analysis, San Diego, v. 24, n. 4-5, p. 469-480, 2011.

YANG, J.; LIU, R. H.; HALIM, L. Antioxidant and antiproliferative activities of common edible nut seeds. LWT - Food Science and Technology, Amsterdam, v. 42, n. 1, p. 1-8, 2009. 